
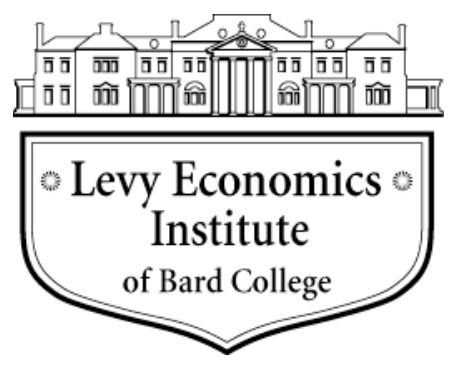

Working Paper No. 883

\title{
Fiscal Policy, Economic Growth and Innovation: An Empirical Analysis of G20 Countries*
}

\author{
by \\ Horst Hanusch \\ University of Augsburg \\ Lekha S. Chakraborty \\ Levy Economics Institute of Bard College \\ National Institute of Public Finance and Policy, New Delhi \\ Swati Khurana \\ Intern, National Institute of Public Finance and Policy, New Delhi
}

February 2017

* This paper was presented at the International Institute of Public Finance conference "Entrepreneurship, Innovation, and Public Policy," held in Lake Tahoe, Calif., August 9-11, 2016; and invited for presentation at the 82nd International Atlantic Economic Conference in Washington, D.C., October 13-16, 2016. Special thanks are due to Michael Stimmelmayr (ETH Zurich) and Pinaki Chakraborty for comments and suggestions. Thanks are due to Amita Manhas for preparing the diagrams.

The Levy Economics Institute Working Paper Collection presents research in progress by Levy Institute scholars and conference participants. The purpose of the series is to disseminate ideas to and elicit comments from academics and professionals.

Levy Economics Institute of Bard College, founded in 1986, is a nonprofit, nonpartisan, independently funded research organization devoted to public service. Through scholarship and economic research it generates viable, effective public policy responses to important economic problems that profoundly affect the quality of life in the United States and abroad.

Levy Economics Institute P.O. Box 5000

Annandale-on-Hudson, NY 12504-5000

http://www.levyinstitute.org

Copyright (C Levy Economics Institute 2017 All rights reserved 


\begin{abstract}
This paper analyzes the effectiveness of public expenditures on economic growth within the analytical framework of comprehensive Neo-Schumpeterian economics. Using a fixed-effects model for G20 countries, the paper investigates the links between the specific categories of public expenditures and economic growth, captured in human capital formation, defense, infrastructure development, and technological innovation. The results reveal that the impact of innovation-related spending on economic growth is much higher than that of the other macro variables. Data for the study was drawn from the International Monetary Fund's Government Finance Statistics database, infrastructure reports for the G20 countries, and the World Development Indicators issued by the World Bank.
\end{abstract}

Keywords: Fiscal Policy; Public Expenditure; Defense; Innovation; Growth; NeoSchumpeterian Economics

JEL Classifications: H5, O30, O38 
The effectiveness of innovation on economic growth and development is an elusive area of research, particularly in the context of G20 countries. Hanusch (2010) and Hanusch and Pyka (2007a and 2007b) are among the scarce studies that have developed an analytical framework called “comprehensive Neo-Schumpeterian economics” (CNSE), which allows one to look empirically at the impact of innovation on economic development. Applying indicator and cluster analysis, their studies detected certain patterns of development for countries in different regions of the world. The CNSE approach is based on a three-pillar concept, integrating the institutional domains of economic, political, and financial conduct. While earlier research has emphasized the financial and industrial linkages, this paper stresses the framework of the public sector, focusing on four of its activities, namely spending for defense, infrastructure, human capital (education and health), and research and development (R\&D).

Within the framework of these four activities of the public sector, in the first case the state offers national security as a pure public good via defense expenditures. In the second case, the state provides capital investment (infrastructure) as a prerequisite for economic development. In the third instance the state is defined as an institution preparing individuals and society for the uncertainties of the future (resilience) via education and health expenditures. The fourth category is closely related to innovation, hence traditionally R\&D expenditures are taken as a proxy for the propensity of a firm or a society to invest in the future by creating new ideas and using them as innovations.

Behind these expenditures stands, in sociopolitical consideration, a notion of the state as an active provider of public services for certain purposes. From an analytical perspective the state is integrated in an institutional or sectoral framework that consists of the public, the financial, and the real sectors. They are all oriented towards the development of an economy as it is formulated in the CNSE approach.

So, what role does a state play when it focuses on resilience by stressing the education and health (human capital) of its citizens in order to master the future and which kind of state is the most relevant one when we focus on economic growth and development? Is it the "security state” or the "development state” (“development” in the sense of catching up) that matters most? Or is it, the "innovation-oriented state," which focuses on R\&D, that has the biggest influence on economic growth? 
To answer these questions we investigate the links between the four categories of public expenditures and economic growth in an empirical model using data for the G20 countries during the period between 2000 and 2012, within the constraints of data availability. The G20 is an economic, financial, and political forum that consists of 19 major economies (both advanced and developing) located in Asia, Europe, Euro-Asia, North and South America, the Middle East, and the Oceanics. Adding the European Union as one entity you get the G20, which is the main economic council of wealthy nations today. The 19 member countries of the G20 together account for about 77 percent of world GDP, 60 percent of world trade, and 62 percent of the world population (Vestergaard 2011). In our study we disintegrate the EU from a single member of the G20 into its individual member states. So, all in all, our sample conveys not only 19 but 43 countries. The data used stems from the electronic database of the IMF's Government Finance Statistics, the infrastructure reports for the G20 countries, and the World Bank’s World Development Indicators (WDI).

Within a panel data model we tested the data for the G20 countries to reveal the following outcome: Public expenditures, especially those related to innovation, have been found to be significantly effective in the development process of the G20 countries. These results hold as being significant when we controlled for defense and human capital spending and turned insignificant in the case of infrastructure development.

The paper is structured as follows. Section 1 gives an overview of the existing literature dealing with the links between innovation and economic growth and identifies the gaps in the empirical literature and section 2 briefly describes the analytical framework of “comprehensive Neo-Schumpeterian economics.” Section 3 deals with the panel data model and its specification and interprets the results. Section 4 concludes.

\section{REVIEW OF THE LITERATURE AND GAPS IN THE RESEARCH}

Endogenous growth models, pioneered by Romer (1986) and Lucas (1988), have tried to analyze the productivity growth effects that occur through the formation of human capital and R\&D. In public finance, Barro’s (1990) pioneering paper established a correlation between public expenditure and economic growth, and since then a wide empirical literature has explored this question using time-series and panel estimations. Barro (1991) also empirically 
analyzed the link between public spending and economic growth in a cross-country framework of 98 countries for the period 1960-85, and Barro and Sala-i-Martin (1995) and Sturm (1998) have highlighted the fact that the marginal product of public capital is much higher than that of private capital.

Nelson and Winter (1982) analyzed innovation as a public good. Innovation activities have significantly positive externalities, which means that public expenditure on innovation is critical to economic growth. Delong and Summers (1991) and Nadiri (1993) also found that the rate of social return from public spending on innovation exceeds the rate of private return.

In recent years, innovation has also had an important place in various empirical studies related to economic growth, conducted at both regional and national levels (Teixeira and Fortuna 2004; Canton, et al. 2005; Batabyal and Nijkamp 2013; Akinwale et al. 2012; Vogel 2012; Jean 2012; Cinnirella and Streb 2013). These studies mostly emphasize that innovation, frequently arising from $R \& D$ activities, is the main engine of a growing economy.

Canton et al. (2005) also argue that the economic growth of a nation is determined by economic and technological factors, such as R\&D intensity and innovations, as well as by human behavior, such as educational attainment. First, human capital can directly enhance total factor productivity. Second, it might strengthen technological activities of firms by innovations, imitations, or adoption of new technologies (Romer 1990; Benhabib and Spiegel 1994; Teixeira and Fortuna 2004; Cinnirella and Streb 2013). In their Schumpeterian endogenous growth model, Aghion and Howitt (1992) showed that R\&D activities can lead to innovation is a prerequisite for technological progress, which will determine economic growth in a Schumpeterian creative destruction process. Furthermore, Fagerberg (2004) demonstrates in his Schumpeterian analysis that innovation becomes a vital component for long-term economic growth.

A considerable empirical literature about the effects of innovation on total factor productivity also exists. For instance, Vogel (2012) examined the effects of R\&D and human capital development on total factor productivity growth. The empirical results provide significant evidence of a positive direct effect of human capital development and a positive indirect effect of R\&D activity on total factor productivity growth for the EU-15 region. Jean (2012) showed that the impact of R\&D and human capital development are positive on regional 
growth in France, while Teixeira and Fortuna (2004) estimated a long-run relationship between total factor productivity and R\&D activity in the context of the Portuguese economy. Their results showed that human capital stock is more important than internal innovation capability when explaining productivity.

The reviewed literature illustrates a huge academic interest in the topic of innovation and economic growth. What is missing, however, is a clear-cut institutional approach that would attach the sources of innovation and growth to the main players in the process of development, namely the public, financial, and real sectors of an economy. This institutional diversification helps in understanding not only the macro structure of an economy but also to identify the influence of each of the three sectors on growth and development.

\section{CNSE AS AN ANALYTICAL FRAMEWORK}

Schumpeterian growth and development models gained their importance in the literature and political practice in the last three decades or so. They can be differentiated into a traditional Schumpeterian approach (model 1), a Neo-Schumpeterian approach (model 2), and a comprehensive Neo-Schumpeterian approach (CNSE) (model 3).

Model 1 goes back to Schumpeter's (1912) famous book, Theory of Economic Development, and his later book, Capitalism, Socialism and Democracy (1942). In addition to risk-taking entrepreneurs (Schumpeter 1912) or corporate innovation management, it reveals the role of innovations as a driving force in the development process (Schumpeter 1942). Technological progress is assumed to be an endogenous process and growth is characterized mainly as a quantitative phenomenon.

Model 2 builds upon model 1, and is improved by also stressing qualitative growth factors and processes emphasizing formal or informal knowledge-based networks, as well as collaborations between firms, governments, universities, and research institutions (Saviotti and Pyka 2004; Wallace 2013).

Model 3 is also based on the principle of innovation as the driving force and engine of development. But, in addition, it stresses the notion that innovation penetrates all spheres of 
socioeconomic life in developed as well as in developing countries. So, it is the institutional setting of the three pillars that characterizes (and to a high degree even dominates) the development process of an economy. Together the three pillars build an institutional architecture in which the dynamic processes of a society take place.

\section{Figure 1a: Institutional Setting in Catch-up Models}

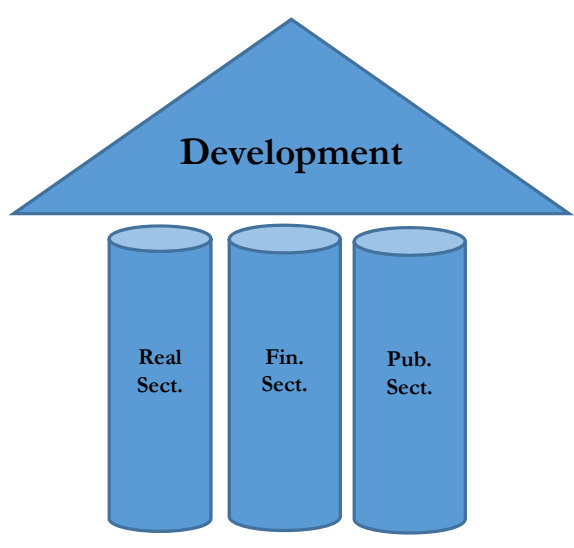

Figure 1b: Institutional Setting in Advanced Development Models

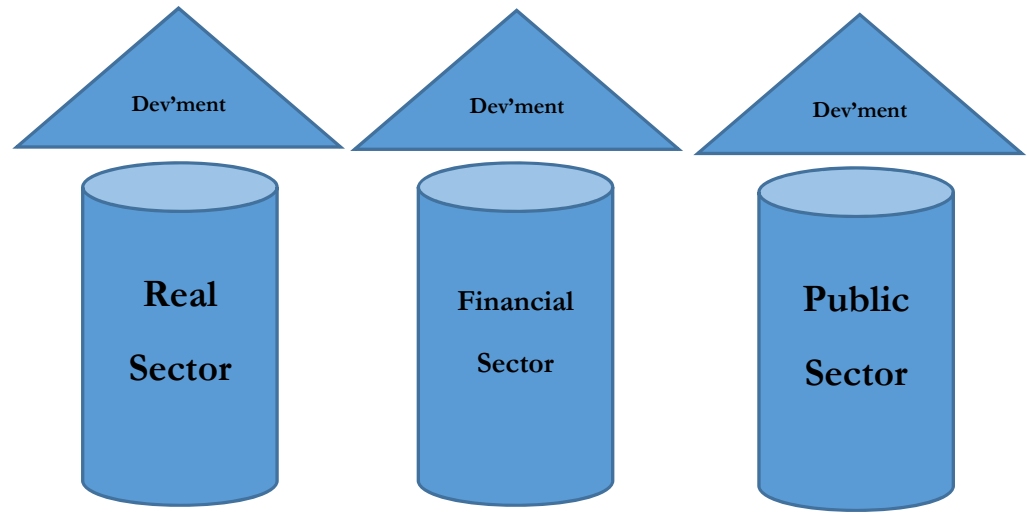

The kind of institutional setting shown in figure 1a is typical for catch-up models of development, especially as they were used by emerging economies in Asia. The pillar closeness and the integrative development strategy give developing countries some special opportunities. For instance, the pillars (sectors) can work together very closely or even intimately to climb up the development ladder. 
The institutional configuration of figure 1b isn’t untypical for advanced capitalistic economies existing in a democratic environment. Here, each of the pillars has a highly elaborate or evolved autonomy. Each one undergoes liberalized development following an evolutionary process of innovation.

Looking at the public sector in each of the institutional configurations, the government or the state has a certain political capacity or even power to influence or direct the process of development through specific budgetary means. On the expenditure side of the budget this is, above all, spending or investing in defense, education and health, and infrastructure, as well as science and research. In this way, the public sector more or less fulfils the role of an “entrepreneurial state” (Mazzucato 2013), actively bringing in its abilities to create and shape development or ensure preparedness for the future through the process of growth and development.

The key questions of this paper are which kind of public activities and which notion of the state within its overall role as an entrepreneur will have the most significant effects on this process. However, before we give an answer by applying an econometric analysis, we would like to have a closer look at the empirical data used in our investigation.

\section{SPECIFYING THE FIXED EFFECTS MODELS AND INTERPRETING THE RESULTS}

Before estimating the panel regressions, we have to deal with nonstationarity and heterogeneity issues in the panel data models. In accordance with Levin and Lin (1992), who tested heterogeneity in unit roots against no unit roots, we tested the variables for economic

growth, R\&D spending, education, and health, as well as infrastructure and defense spending for plausible unit roots, using Levin-Lin-Chu, Breitung, Im-Pesaran-Shin (IPS), and Fisher methodology. The results show that the variables have no roots. All variables are stationary (table 1). 
Table 1: Unit Root Test Results of Economic Growth, Innovation, Education, Health, Infrastructure, and Defense Expenditure

ECONOMIC GROWTH

\begin{tabular}{|c|c|c|c|c|}
\hline Method & Statistic & Prob.** & $\begin{array}{l}\text { Cross- } \\
\text { sections }\end{array}$ & Obs \\
\hline \multicolumn{5}{|c|}{ Null: Unit root (assumes common unit root process) } \\
\hline Levin, Lin \& Chu t* & -13.39 & 0.00 & 43 & 400 \\
\hline \multicolumn{5}{|c|}{ Null: Unit root (assumes individual unit root process) } \\
\hline Im, Pesaran and Shin W-stat & -7.69 & 0.00 & 43 & 400 \\
\hline ADF - Fisher Chi-square & 214.95 & 0.00 & 43 & 400 \\
\hline PP - Fisher Chi-square & 151.74 & 0.00 & 43 & 429 \\
\hline
\end{tabular}

\section{INNOVATION}

\begin{tabular}{|c|c|c|c|c|}
\hline Method & Statistic & Prob.** & $\begin{array}{l}\text { Cross- } \\
\text { sections }\end{array}$ & Obs \\
\hline \multicolumn{5}{|c|}{ Null: Unit root (assumes common unit root process) } \\
\hline Levin, Lin \& Chu t* & 1.41 & 0.92 & 41 & 369 \\
\hline \multicolumn{5}{|c|}{ Null: Unit root (assumes individual unit root process) } \\
\hline Im, Pesaran and Shin W-stat & 3.21 & 0.99 & 41 & 369 \\
\hline ADF - Fisher Chi-square & 52.54 & 0.99 & 41 & 369 \\
\hline PP - Fisher Chi-square & 57.99 & 0.97 & 41 & 384 \\
\hline
\end{tabular}

$\overline{\overline{\text { INFRASTRUCTURE }}}$

\begin{tabular}{|c|c|c|c|c|}
\hline Method & Statistic & Prob.** & $\begin{array}{l}\text { Cross- } \\
\text { sections }\end{array}$ & Obs \\
\hline \multicolumn{5}{|c|}{ Null: Unit root (assumes common unit root process) } \\
\hline Levin, Lin \& Chu t* & -12.10 & 0.00 & 12 & 117 \\
\hline \multicolumn{5}{|c|}{ Null: Unit root (assumes individual unit root process) } \\
\hline Im, Pesaran and Shin W-stat & -8.88 & 0.00 & 12 & 117 \\
\hline ADF - Fisher Chi-square & 107.79 & 0.00 & 12 & 117 \\
\hline PP - Fisher Chi-square & 151.86 & 0.00 & 12 & 120 \\
\hline
\end{tabular}

\section{DEFENSE}

\begin{tabular}{|c|c|c|c|c|}
\hline Method & Statistic & Prob.** & $\begin{array}{l}\text { Cross- } \\
\text { sections }\end{array}$ & Obs \\
\hline \multicolumn{5}{|c|}{ Null: Unit root (assumes common unit root process) } \\
\hline Levin, Lin \& Chu t* & -10.69 & 0.00 & 35 & 287 \\
\hline \multicolumn{5}{|c|}{ Null: Unit root (assumes individual unit root process) } \\
\hline Im, Pesaran and Shin W-stat & -3.36 & 0.00 & 33 & 281 \\
\hline ADF - Fisher Chi-square & 114.22 & 0.00 & 35 & 287 \\
\hline PP - Fisher Chi-square & 127.58 & 0.00 & 35 & 294 \\
\hline
\end{tabular}


EDUCATION

\begin{tabular}{|c|c|c|c|c|}
\hline Method & Statistic & Prob.** & $\begin{array}{l}\text { Cross- } \\
\text { sections }\end{array}$ & Obs \\
\hline \multicolumn{5}{|c|}{ Null: Unit root (assumes common unit root process) } \\
\hline Levin, Lin \& Chu t* & -6.92 & 0.00 & 35 & 288 \\
\hline \multicolumn{5}{|c|}{ Null: Unit root (assumes individual unit root process) } \\
\hline Im, Pesaran and Shin W-stat & -1.63 & 0.05 & 33 & 282 \\
\hline ADF - Fisher Chi-square & 99.25 & 0.01 & 35 & 288 \\
\hline PP - Fisher Chi-square & 86.78 & 0.08 & 35 & 294 \\
\hline \multicolumn{5}{|l|}{ HEALTH } \\
\hline Method & Statistic & Prob. $* *$ & $\begin{array}{l}\text { Cross- } \\
\text { sections }\end{array}$ & Obs \\
\hline \multicolumn{5}{|c|}{ Null: Unit root (assumes common unit root process) } \\
\hline Levin, Lin \& Chu t* & -6.39 & 0.00 & 35 & 289 \\
\hline \multicolumn{5}{|c|}{ Null: Unit root (assumes individual unit root process) } \\
\hline Im, Pesaran and Shin W-stat & -1.14 & 0.12 & 33 & 283 \\
\hline ADF - Fisher Chi-square & 80.96 & 0.17 & 35 & 289 \\
\hline PP - Fisher Chi-square & 100.54 & 0.00 & 35 & 293 \\
\hline
\end{tabular}

Notes: ** Probabilities for Fisher tests are computed using an asymptotic Chi-square distribution.

All other tests assume asymptotic normality.

The descriptive statistics of the macro variables show up in table 2.

Table 2: Descriptive Statistics of the Macro Variables

\begin{tabular}{|c|c|c|c|c|c|}
\hline & GDP growth & Education & Health & Innovation & Defense \\
\hline Mean & 0.77 & 11.13 & 8.42 & 0.77 & 6.11 \\
\hline Median & 0.74 & 10.87 & 10.47 & 0.74 & 5.25 \\
\hline Maximum & 1.75 & 30.54 & 16.87 & 1.75 & 12.02 \\
\hline Minimum & 0.04 & 1.29 & 0.12 & 0.04 & 2.48 \\
\hline Std. Dev. & 0.35 & 5.64 & 5.08 & 0.35 & 2.57 \\
\hline Skewness & 0.70 & 0.21 & -0.43 & 0.70 & 0.82 \\
\hline Kurtosis & 3.13 & 3.97 & 1.80 & 3.13 & 2.54 \\
\hline Jarque-Bera & 5.41 & 3.05 & 5.85 & 5.41 & 7.85 \\
\hline Probability & 0.06 & 0.21 & 0.05 & 0.06 & 0.01 \\
\hline Sum & 49.61 & 712.67 & 539.31 & 49.61 & 391.50 \\
\hline Sum Sq. Dev. & 7.84 & 2004.78 & 1631.63 & 7.84 & 416.69 \\
\hline
\end{tabular}

Source: Authors' computations.

Now we can specify our fixed effects models as follows:

(i) $\quad G=\alpha+\beta_{1} d e f_{i t}+\beta_{2} i n v_{i t}+\mu_{i t}$

(ii) $\quad G=\alpha+\beta_{1} d e f_{i t}+\beta_{2} h c a p_{i t}+\beta_{3} i n v_{i t}+\mu_{i t}$

(iii) $\quad G=\alpha+\beta_{1} d e f_{i t}+\beta_{2}$ hcap $_{i t}+\beta_{3}$ infra $_{i t}+\beta_{4} i n v_{i t}+\mu_{i t}$ 
where:

$G$ represents GDP growth rate;

def represents growth rate of defense expenditure;

hcap represents growth rate of expenditure on human capital (education and health);

inv represents R\&D expenditure as a percentage of GDP; and

Infra includes expenditure on energy, telecom, water, sanitation, and transport.

Here "i" stands for a particular country and "t" for a particular year.

To analyze the link between the different categories of public spending and economic growth we used all three fixed effects models. While model 1 incorporates fiscal spending on defense as a control variable, models 2 and 3, respectively, control for human capital and infrastructure spending variables. All the expenditure variables are expressed in growth rates.

We estimated the pooled regressions with cross-section weights (pooled EGLS) for two scenarios. In scenario 1, we aggregated the spending for health and education to get the growth rates of total expenditures in this area. In scenario 2, we reestimated the pooled regressions with cross-section weights by aggregating the public spending on education and health, along with spending on innovation, infrastructure, and defense.

The results in scenario 1 show that public expenditure on innovation and human capital formation (aggregate spending on health and education) matter for economic growth. However, 1 percent of spending on R\&D would increase economic growth by 9.57 percent, while a 1 percent increase in spending on human capital would increase economic growth by only 0.29 percent. Public expenditures on infrastructure and defense are found to be insignificant in their impact on economic growth (table 3).

The results for scenario 2 revealed that only innovation matters for growth. The coefficients showed that a 1 percent increase in spending on $R \& D$ would increase economic growth by 9.92 percentage points (table 3 ). 
Table 3: Results from Pooled Regressions with Cross-section Weights

Scenario 1

\begin{tabular}{lllll}
\hline \hline Variable & Coefficient & Std. Error & t-Statistic & Prob. \\
\hline \hline ?E+?H & 0.28 & 0.08 & 3.52 & 0.00 \\
?RD & 9.57 & 4.68 & 2.04 & 0.04 \\
?D & 0.06 & 0.57 & 0.11 & 0.90 \\
?I & 0.01 & 0.01 & 0.96 & 0.33 \\
\hline \hline & Weighted Statistics & \\
\hline \hline R-squared & 0.07 & Mean dependent var & 17.82 \\
Adjusted R-squared & 0.02 & S.D. dependent var & 19.31 \\
S.E. of regression & 16.54 & Sum squared resid & 16419.70 \\
Durbin-Watson stat & 1.65 & & \\
\hline \hline & Unweighted Statistics & 12.98 \\
\hline \hline
\end{tabular}

Scenario 2

\begin{tabular}{lllll}
\hline \hline Variable & Coefficient & Std. Error & t-Statistic & Prob. \\
\hline \hline ?E & 0.25 & 0.19 & 1.30 & 0.19 \\
?H & 0.30 & 0.31 & 0.97 & 0.33 \\
?RD & 9.92 & 4.78 & 2.07 & 0.04 \\
?D & 0.03 & 0.58 & 0.05 & 0.95 \\
?I & 0.01 & 0.01 & 0.96 & 0.33 \\
\hline \hline & Weighted Statistics & \\
\hline \hline R-squared & 0.07 & & \\
Adjusted R-squared & 0.003 & & \\
S.E. of regression & 16.69 & & \\
Durbin-Watson stat & 1.650 & & \\
\hline \hline & Unweighted Statistics & \\
\hline \hline
\end{tabular}

Source: Authors’ computations.

\section{CONCLUSION AND POLICY RESULTS}

The paper examines the relationship between fiscal policy (public spending oriented towards innovation measured by R\&D expenditures as a proxy variable) and economic growth for the G20 countries over the period 2000-10 using a panel data analysis. In this analysis we included human capital (education and health), infrastructure, and defense spending as 
control variables to analyze the impact of innovation on the GDP growth rate in a multivariate framework. The government finance statistics yearbooks have been used to compile the data for defense spending and human capital (health and education), while the data for GDP, R\&D, and infrastructure (energy, telecom, water, sanitation, and transport) were collected from the WDI.

The panel data regression results show that public spending on innovation has a significant impact on economic growth in the G20 countries. The pooled regression with cross-section weights also shows that the coefficient of innovation is much higher than the coefficients of the other variables. This result has a remarkable policy implication. Public expenditures for R\&D (innovation) have a significant positive macroeconomic impact on economic growth, so investment in R\&D is crucial for a sustainable economic growth in the G20 countries. This kind of GDP growth might be called "innovation driven" and it is in full accordance with Schumpeterian ideas of economic development. 


\section{REFERENCES}

Aghion, P., and P. Howitt. 1992. “A Model of Growth Through Creative Destruction.” Econometrica 60(2): 323-51.

Akinwale, Yusuf O., Abolaji D. Dada, Adekemi J. Oluwadare, Olalekan A. Jesuleye, and Willie O. Siyanbola. 2012. "Understanding the Nexus of R\&D, Innovation and Economic Growth in Nigeria.” International Business Research 5(11): 187-96.

Barro, R.J. 1990. “Government Spending in a Simple Model of Endogenous Growth.” Journal of Political Economy 98: 103-25.

—. 1991. "Economic growth in a cross section of countries.” The Quarterly Journal of Economics 106(2): 407-43.

Barro, R., and X. Sala-i-Martin. 1995. Economic Growth. Boston: McGraw-Hill and MIT Press.

Batabyal, A., and P. Nijkamp. 2013. "Human capital use, innovation, patent protection, and economic growth in multiple regions.” Economics of Innovation and New Technology 22(2): 113-26.

Benhabib, J., and M.M. Spiegel. 1994. "The role of human capital in economic development: Evidence from aggregate cross-country data.” Journal of Monetary Economics 34: 143-73.

Canton, Erik, Bert Minne, Ate Nieuwenhuis, Bert Smid, and Marc van der Steeg. 2005. "Human Capital, R\&D and Competition in Macroeconomic Analysis.” ENEPRI Working Paper 38. The Hague: ENEPRI.

Cinnirella, Francesco, and Jochen Streb. 2013. "The Role of Human Capital and Innovation in Prussian Economic Development.” Cesifo Working Paper 4391. Munich: Cesifo.

DeLong, J.B., and L.H. Summers. 1991. "Equipment Investment and Economic Growth.” Quarterly Journal of Economics 106(2): 445-502.

Fagerberg, J. 2004. “Innovation: A Guide to the Literature.” In J. Fagerberg, D. Mowery, and R. Nelson (eds.), The Oxford Handbook of Innovation. Oxford: Oxford University Press.

Hanusch, H., and A. Pyka. 2007a. “The Principles of Neo-Schumpeterian Economics.” Cambridge Journal of Economics 31(2): 275-89.

— 2007b. “Applying a Comprehensive Neo-Schumpeterian Approach to Europe and its Lisbon Agenda.” In R. Tilly, P. Welfens, and M. Heise (eds.), 50 Years of EU Dynamics, Integration-Financial Markets and Innovations. Berlin, Heidelberg, and New York: Springer. 
Hanusch, H., A. Pyka, and F. Wackermann. 2010. "Patterns of Future-Orientation in Central and Eastern Europe.” Köz-Gazdaság (Quarterly Journal, Faculty of Economics, Corvinus University Budapest), Special English Language Issue, "Economic Theory and Policy”: 173-89.

Hanusch, H. 2010. "Fighting the Crisis: Public Sector Governance in a Comprehensive NeoSchumpeterian System.” Homo Oeconomicus 27(1/2): 89-104.

Jean, G. 2012. "Human Capital and R\&D Driven Growth: Analysis for France at Regional Level on The Long Run.” Université de Franche-Comté Working Paper 274. Besançon: Université de Franche-Comté.

Levin, A., and C.F. Lin. 1992. "Unit Root Test in Panel Data: Asymptotic and Finite Sample Properties.” Discussion Paper No. 92-93. San Diego: University of California at San Diego.

Lucas, G. 1988. “On The Mechanics of Economic Development.” Journal of Monetary Economics 22: 3-42.

Mazzucato, M. 2013. The Entrepreneurial State, Debanking Private vs. Public Sector Myths in Risks and Innovation. London and New York: Anthem Press.

Nadiri, M.I. 1993. “Innovations and Technological Spillovers.” NBER Working Paper 4423. Cambridge, MA: National Bureau of Economic Research.

Nelson, R.R., and S.G. Winter. 1982. “The Schumpeterian Tradeoff Revised.” American Economic Review 72.

Romer, P.M. 1986. “Increasing Returns and Long Run Growth.” Journal of Political Economy 94(5): 1002-37.

— 1990. “Endogenous Technological Change.” Journal of Political Economy 98(5): 71-102.

Saviotti, P.P., and A. Pyka. 2008. "Product Variety, Competition and Economic Growth." Journal of Evolutionary Economics 18(3-4): 323-47.

Schumpeter, J.A. 1912. Theorie der Wirtschaftlichen Entwicklung. Leipzig: Dunker \& Humblot.

— 1942. Capitalism, Socialism and Democracy. New York: Harper \& Brothers.

Sturm, J.E. 1998. Public Capital Expenditure in OECD Countries: The Causes and Impact of the Decline in Public Capital Spending. Aldershot: Edward Elgar.

Teixeiara, A., and N. Fortuna. 2004. "Human Capital, Innovation Capability and Economic Growth.” FEP Working Paper No. 131. Porto: Universidade do Porto.

Vestergaard, Jakob. 2011. G20 and Beyond: Towards Effective Global Economic Governance. DIIS Report. Copenhagen: Danish Institute of International Studies. 
Vogel, J. 2012. “The Two Faces of R\&D and Human Capital: Evidence from Western European Regions.” University of Oxford Working Paper 599. Oxford: University of Oxford.

Wallace, R. 2013. "A New Formal Approach to Evolutionary Processes in Socio-Economic Systems.” Journal of Evolutionary Economics 23(1): 1-15.

World Bank. 1999. World Development Report 1998-1999: Knowledge for Development. New York: Oxford University Press. 